IP Periodica Polytechnica Civil Engineering

60(3), pp. 3133222016

DOI: $10.3311 /$ PPci.7904

Creative Commons Attribution (1)

RESEARCH ARTICLE

\section{Mechanical Properties of Concrete with Copper Slag and Fly Ash by DT and NDT}

\author{
Sumathy Raju, Brindha Dharmar
}

Received 12-01-2015, revised 26-06-2015, accepted 29-09-2015

\begin{abstract}
This paper presents a laboratory study about the influence of combination of Fly Ash (FA) and Copper Slag (CS) on the mechanical properties of concrete. Concrete mixtures are made with 10\%, 20\% and 30\% replacement of cement with low lime (class F) fly ash by mass and fine aggregate is replaced by CS from $0-100 \%$ with an increment of $20 \%$ by volume. On the hardened concrete, Destructive Test (DT) methods such as compressive strength (7,28, 56 and 90 days), split tensile strength (28 days) and flexural strength (28 days) are determined. Moreover, Non-Destructive Test (NDT) methods such as Ultrasonic Pulse Velocity (UPV) and Digital Schmidt Rebound Hammer (RH) tests are also determined. Based on the experimental results, both NDT and DT techniques, the results are favorable for concrete with industrial wastes such as Fly Ash and Copper Slag and also superior to control concrete.
\end{abstract}

\section{Keywords}

FlyAsh - Copper slag · Mechanical properties - Destructive . Non-destructive test

\section{Sumathy Raju}

Alagappa Chettiar College of Engineering and Technology, Government of Tamil Nadu Institution, Karaikudi, Tamil Nadu, India

e-mail: sr.sumathy5@gmail.com

\section{Brindha Dharmar}

Thiagarajar College of Engineering, Madurai, Tamil Nadu, India e-mail: dbrindha@yahoo.co.in

\section{Introduction}

Utilization of industrial waste is very essential for developing countries like India. It is because of lack of land for dumping the waste materials, depletion of natural aggregates, energy saves and cost saving. While manufacturing cement, the environment faces equivalent amount of $\mathrm{co}_{2}$ which is very harmful to the nature. In addition, due to scarcity of natural resources the waste materials must be properly utilized to preserve the environment as eco-friendly. This scenario leads to the utilization of by- products such as Fly Ash (FA) and Copper Slag (CS) as replacements for cement and fine aggregates, respectively. Indian Copper companies - Sterlite Industries, Hindalco, and Hindustan have contributed to the production of major quantities of copper. Copper slag is a by-product obtained from the smelting and refining of copper. Production of one tonne of copper generates approximately 2.2 - 3.0 tonnes copper slag [1]. Similarly, a country's industrial growth depends on the availability of power. In India also, coal is a major source of fuel for power generation. About $60 \%$ power is produced using coal as fuel. Indian coal has low calorific value $(3000-3500 \mathrm{kcal})$ and very high ash content $(30-45 \%)$. As a result huge quantity of ash is generated in the coal based thermal power stations. During 2005 - 2006 about 112 million tonnes of ash have been generated in 125 power stations. With the present growth in power sector, it is expected that the ash generation would reach 225 million tonnes by 2017 [2]. In this regard, the waste disposal has become a severe social and environmental problem. Hence, waste materials can be substituted for raw materials especially for cement production or can partially be replaced for cement and fine aggregate in concrete alone. It will reduce the depletion of natural aggregate and maintain the green environment.

CS has favorable mechanical and chemical characteristics that lead to its utilization for value added products such as cement, fill, ballast, abrasive, cutting tools, aggregate, roofing granules, glass, tiles etc. [3] CS is substituted for fine aggregate due to possessing superior mechanical properties and they may be of cheaper varieties than the similar conventional material [4-10]. The pozzolanic property of FA makes it a resource for making cement and other ash based product. When FA is present in 
the concrete mass, it plays dual role for the strength development. FA reacts with surplus lime and produces additional $\mathrm{C}$ $\mathrm{S}-\mathrm{H}$ gel which renders additional strength to the concrete. The un-reactive portion of fly ash acts as micro aggregates and fills up the matrix to condense packing effect which results increased strength [11-18]. Many researchers have discretely investigated the use of CS and FA as replacement for cement, coarse and fine aggregate, respectively. But there is no much research on the mechanical properties such as destructive and non-destructive tests for concrete where cement is replaced by FA from $0 \%$ to $30 \%$ and fine aggregate is replaced by CS from $0 \%$ to $100 \%$. But, attempts have been done to relate Rebound Hammer and Ultrasonic Pulse Velocity to concrete strength as demonstrated [19.21]. Results of these two methods are largely affected by many factors. Therefore, it is assured that the use of more than one method yields more reliable results. Of a number of purely NDT tests, the Rebound Hammer and Ultrasonic Pulse Velocity combinations are the most commonly used.

Hence, in this work concrete compressive strengths assessing by NDT techniques such as Ultrasonic Pulse Velocity and the Schmidt Rebound Hammer are used. The first method is used to measure the pulse velocity in concrete from the direct transmission method while the second method evaluates concrete compressive strength through measuring its surface hardness. Thus, the main aim of this effort is to increase exploitation of copper slag in concrete and compensate the early strength when adding fly ash in concrete and also to study about mechanical properties of concrete with industrial waste by using Destructive Testing (DT) and Non-Destructive Testing techniques (NDT).

\section{Experimental Study}

\subsection{Materials and mix proportions}

Ordinary Portland cement (43 grade) is used for entire research, which confirms the current specifications as described in IS8112 (part1):2013 [22]. The properties of the cement are given in the Table 1. A class F fly ash obtained from Thermal Power Plant, Salem (Tamil Nadu),India is used and fly ashes are classified as low calcium fly ash which has satisfied as per the IS3812(part1):2003 [23] and Specific gravity of fly ash 2.18. The term specific gravity, refers to the ratio of the density of a solid or liquid to the density of water. The term can also refer to the ratio of the density of a gas to the density of dry air at standard temperature and pressure, Specific gravity is a dimensionless quantity; that is, it is not expressed in units.Locally available river sand of zone II and crushed blue granite stone of maximum size $20 \mathrm{~mm}$ are used as fine aggregate and coarse aggregate, respectively [24]. Copper slag from Sterlite Industries India Limited (SIIL), Tuticorin, Tamil Nadu is utilized.The properties of these aggregates and copper slag are given in Table 2. It can be seen from these results density of the copper is very contrast to the density of sand, which leads to the increase in concrete density as more copper slag was added. Chemical properties of class F FA and CS are given in Table 3, Gradation tests are conducted on aggregates and gradation curves are represented in Fig. 1 and Fig. 2, respectively. The fineness modulus is a numerical index of fineness, giving some idea of the mean size of the particle present in the entire body of the aggregate. The sum of the cumulative percentages retained on the sieves divide by 100 give the fineness modulus. Fineness modulus of the CS has high compared to river sand. This signifies that copper slag is coarser than the fine aggregate.

Tab. 1. Properties of Cement

\begin{tabular}{cc}
\hline Initial setting time & $90 \mathrm{~min}$ \\
\hline Final setting time & $420 \mathrm{~min}$ \\
\hline Standard consistency & $36 \%$ \\
\hline Specific gravity & $3.15[-]$ \\
\hline
\end{tabular}

The concrete mixture confirms to IS 10262-2009 [25]. Cement and water cement ratio is kept constant for each mix proportion as $380 \mathrm{~kg} / \mathrm{m}^{3}$ and 0.4 , respectively. Cement is replaced by FA (class F) at 10\%, $20 \%$ and $30 \%$ of mass and fine aggregate is replaced by CS from the range of $0 \%-100 \%$ with an increment rate of $20 \%$ by volume. Total of twenty four concrete mix proportions are prepared and given in Table 4

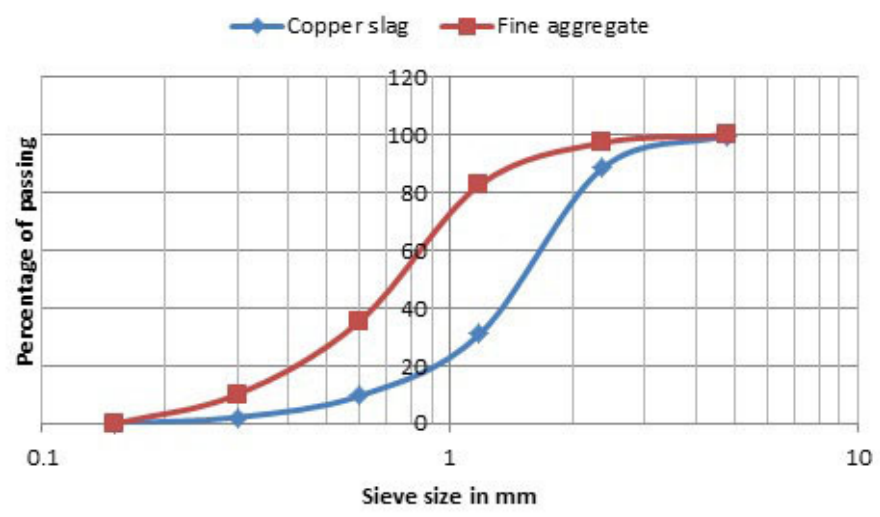

Fig. 1. Particle size distribution for CS and Fine aggregate

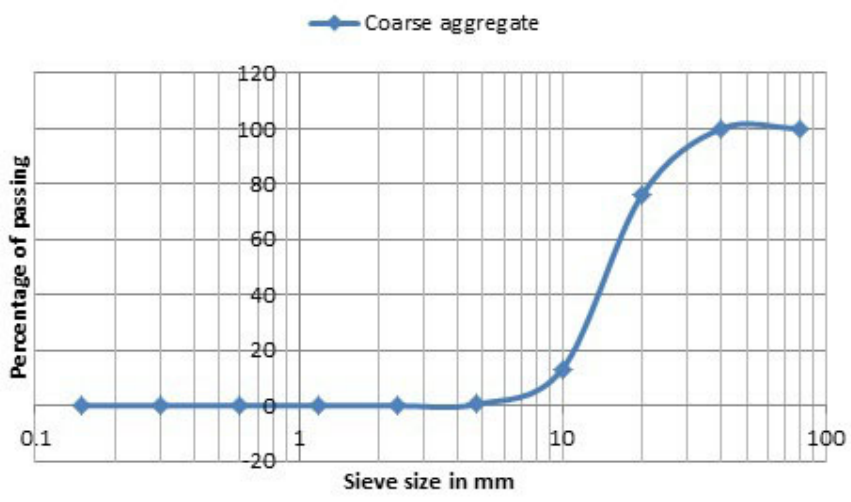

Fig. 2. Particle size distribution for coarse aggregate

\subsection{Sample preparation}

The materials are mixed properly and ensure uniformity and water was added with constant water cement ratio is 0.4 then 
Tab. 2. Properties of Fine aggregate, copper slag and Coarse aggregate

\begin{tabular}{cccc}
\hline Details of testing & Fine aggregate & Copper slag & Coarse aggregate \\
\hline Specific gravity $[-]$ & 2.5 & 3.52 & 2.75 \\
\hline Fineness modulus [-] & 2.74 & 3.68 & 7.6 \\
\hline Bulk density $\left[\mathrm{kg} / \mathrm{m}^{3}\right]$ & 1420 & 1750 & 1380 \\
\hline
\end{tabular}

Tab. 3. Chemical composition for Fly ash (class F) and Copper slag

\begin{tabular}{ccc}
\hline Parameter & Class F Fly ash,\% 2 & Copper slag, $\%$ ] \\
\hline $\mathrm{SiO}_{2}$ & 50.50 & 25.84 \\
\hline $\mathrm{Al}_{2} \mathrm{O}_{3}$ & 26.57 & 0.22 \\
\hline $\mathrm{Fe}_{2} \mathrm{O}_{3}$ & 13.77 & 68.29 \\
\hline $\mathrm{Ai}_{2} \mathrm{O}_{3}+\mathrm{Fe}_{2} \mathrm{O}_{3}$ & 90.84 & - \\
\hline $\mathrm{CaO}$ & 2.13 & 0.15 \\
\hline $\mathrm{Mgo}$ & 1.54 & - \\
\hline $\mathrm{So}_{3}$ & 0.41 & 0.11 \\
\hline $\mathrm{K}_{2} \mathrm{O}$ & 0.77 & 0.23 \\
\hline $\mathrm{Na}_{2} \mathrm{O}$ & 0.45 & 0.58 \\
\hline $\mathrm{P}_{2} \mathrm{O}_{5}$ & 1.00 & - \\
\hline $\mathrm{Chloride}$ & - & 0.018 \\
\hline Loss of ignition & 0.6 & 6.59 \\
\hline $\mathrm{Cuo}$ & - & 1.2 \\
\hline Insoluble residue & - & 14.88 \\
\hline Sulphide sulphur & - & 0.25 \\
\hline $\mathrm{Mn} \mathrm{O}_{3}$ & - & 0.22 \\
\hline Tio & & 0.41 \\
\hline
\end{tabular}

mixed properly. The concrete is placed to standard size cast ion moulds, compaction of concrete was carried out by vibration table. The specimens $150 \mathrm{~mm}$ x $150 \mathrm{~mm}$ x $150 \mathrm{~mm}$ for compressive strength, $150 \mathrm{~mm}$ diameter and $300 \mathrm{~mm}$ long cylinders for splitting tensile strength and $100 \mathrm{~mm} \times 100 \mathrm{~mm} \times 500 \mathrm{~mm}$ prisms for flexural strength. After 24-hours specimens are demoulded and transferred to curing tank and tested at required age.

\subsection{Test procedure}

Mechanical properties of concrete by DT and NDT are investigated in this study. The tests are performed to determine the mechanical properties like compressive strength, splitting tensile strength and flexural strength. Table 5 outlines the experimental programme of this study. Tests are carried out on hardened concrete specimens to evaluate their mechanical properties (destructive and non-destructive) with the IS conformance [26-28]. At the required age of testing, the specimens are removed from the curing tank and sundried before tested for strength. Three specimens are tested for each replacement level and average is recorded. Compressive strength of the $150 \mathrm{~mm}$ cubes specimens are determined at 7, 28, 56, and 90 days. The compressive strength is calculated using the following equation.

$$
\text { Compressive strength }=P / A
$$

Where, $\mathrm{P}$ is peak load $(\mathrm{N})$ in the test, $\mathrm{A}$ is area of cross section in $\mathrm{mm}^{2}$.
Splitting tensile strength tests are carried out on $150 \mathrm{~mm}$ diameter $x 300 \mathrm{~mm}$ long cylinders at 28 days of curing age. The maximum load at failure reading was taken and the split tensile strength is calculated using following equation.

$$
\text { Splitting tensile strength }\left(\mathrm{N} / \mathrm{mm}^{2}\right)=2 P / \pi L D
$$

Where, $P$ is the ultimate load $(\mathrm{N})$ at failure, $L$ is length of specimen $(\mathrm{mm})$ and $D$ is diameter of cylindrical specimen $(\mathrm{mm})$.

Flexural strength tests are carried out on $100 \mathrm{~mm}$ $\mathrm{x} 100 \mathrm{~mm} \times 500 \mathrm{~mm}$ prisms with centre point loading at 28 days of curing age. The flexural strength calculated by the following equation.

$$
\text { Flexural strength }=P l / b d^{2}
$$

where, $P$ is maximum load $(\mathrm{N})$ applied to the specimen, $L$ is length in mm of the span on which the specimens is supported, $d$ is measured depth in mm of the specimen at the point of failure and $b$ is measured width in mm of the specimen.

Before conducting compressive strength (DT), NDT tests are conducted at 28 days curing period specimens. Quality of concrete in terms of density, homogeneity, strength and uniformity of the concrete is verified by the UPV (direct transmission method) and assessing compressive strength of concrete cubes by RH. And also powdered samples are collected for further extensive research for XRD, SEM and $\mathrm{pH}$ value etc. 
Tab. 4. Mix proportions for M30 grade

\begin{tabular}{|c|c|c|c|c|c|c|c|}
\hline \multirow{2}{*}{\multicolumn{2}{|c|}{$\begin{array}{l}\text { Replacement \% of Fly ash and } \\
\text { Copper slag }\end{array}$}} & \multirow{3}{*}{$\begin{array}{c}\begin{array}{c}\text { Cement } \\
\left(\mathrm{kg} / \mathrm{m}^{3}\right)\end{array} \\
380\end{array}$} & \multirow{3}{*}{$\begin{array}{c}\begin{array}{c}\text { Fly ash } \\
\left(\mathrm{kg} / \mathrm{m}^{3}\right)\end{array} \\
-\end{array}$} & \multirow{3}{*}{$\begin{array}{c}\begin{array}{c}\text { Fine aggregate } \\
\left(\mathrm{kg} / \mathrm{m}^{3}\right)\end{array} \\
596\end{array}$} & \multirow{3}{*}{\multicolumn{2}{|c|}{$\begin{array}{c}\begin{array}{c}\text { Coarse } \\
\text { aggregate } \\
\left(\mathrm{kg} / \mathrm{m}^{3}\right)\end{array} \\
1293\end{array}$}} & \multirow{3}{*}{$\begin{array}{r}\begin{array}{r}\text { Water } \\
\left(\mathrm{kg} / \mathrm{m}^{3}\right)\end{array} \\
152\end{array}$} \\
\hline & & & & & & & \\
\hline FAO & CSO & & & & & & \\
\hline FAO & CS20 & 380 & 0 & 520 & 183 & 1293 & 152 \\
\hline FAO & CS40 & 380 & 0 & 390 & 366 & 1293 & 152 \\
\hline FA0 & CS60 & 380 & 0 & 260 & 549 & 1293 & 152 \\
\hline FA0 & CS80 & 380 & 0 & 131 & 738 & 1293 & 152 \\
\hline FA0 & CS100 & 380 & 0 & 0 & 922 & 1293 & 152 \\
\hline FA10 & CSO & 342 & 38 & 596 & 0 & 1293 & 152 \\
\hline FA10 & CS20 & 342 & 38 & 520 & 183 & 1293 & 152 \\
\hline FA10 & CS40 & 342 & 38 & 390 & 366 & 1293 & 152 \\
\hline FA10 & CS60 & 342 & 38 & 260 & 549 & 1293 & 152 \\
\hline FA10 & CS80 & 342 & 38 & 131 & 738 & 1293 & 152 \\
\hline FA10 & CS100 & 342 & 38 & 0 & 922 & 1293 & 152 \\
\hline FA20 & CSO & 304 & 76 & 596 & 0 & 1293 & 152 \\
\hline FA20 & CS20 & 304 & 76 & 520 & 183 & 1293 & 152 \\
\hline FA20 & CS40 & 304 & 76 & 390 & 366 & 1293 & 152 \\
\hline FA20 & CS60 & 304 & 76 & 260 & 549 & 1293 & 152 \\
\hline FA20 & CS80 & 304 & 76 & 131 & 738 & 1293 & 152 \\
\hline FA20 & CS100 & 304 & 76 & 0 & 922 & 1293 & 152 \\
\hline FA30 & CSO & 266 & 114 & 596 & 0 & 1293 & 152 \\
\hline FA30 & CS20 & 266 & 114 & 520 & 183 & 1293 & 152 \\
\hline FA30 & CS40 & 266 & 114 & 390 & 366 & 1293 & 152 \\
\hline FA30 & CS60 & 266 & 114 & 260 & 549 & 1293 & 152 \\
\hline FA30 & CS80 & 266 & 114 & 131 & 738 & 1293 & 152 \\
\hline FA30 & CS100 & 266 & 114 & 0 & 922 & 1293 & 152 \\
\hline
\end{tabular}

\section{Results and Discussions}

\subsection{Compressive strength}

Compressive strength test is conducted at 7, 28, 56 and 90 days curing periods for all mix proportions by using Compression testing machine $2000 \mathrm{kN}$ capacity (Fig. 3). Compressive strength results are given from figures [4-7]. From these results, the early strength of concrete with FA alone is lower and higher strength has been developed after 56-90 days. At the early age's, fly ash exhibits very little cementing value but at later ages, when liberated surplus lime resulting from hydration of cement reacts with FA and contributes considerable strength to the concrete.

Combination of both industrial wastes (CS and FA) reacts with cement and produce binding properties to the concrete hence; it has not affected the strength at early age to later age. Based on the 90 days strength results, from $0 \%$ to $10 \% \mathrm{FA}$ is replaced for cement. Optimum strength is reached, when $40 \%$ copper slag is replaced for fine aggregate. It is inferred from the available results that $40 \%$ of copper slag gets more density packing hence, strength is increased. In concrete with $20 \%$ to $30 \%$ FA replacement for cement, ultimate strength is reached when $80 \% \mathrm{CS}$ is replaced for fine aggregate. Because of the reaction of FA and CS react with surplus lime and it offers additional binding properties to the concrete and un-reacted fly ash acts as micro aggregates. It also fills the voids in the concrete

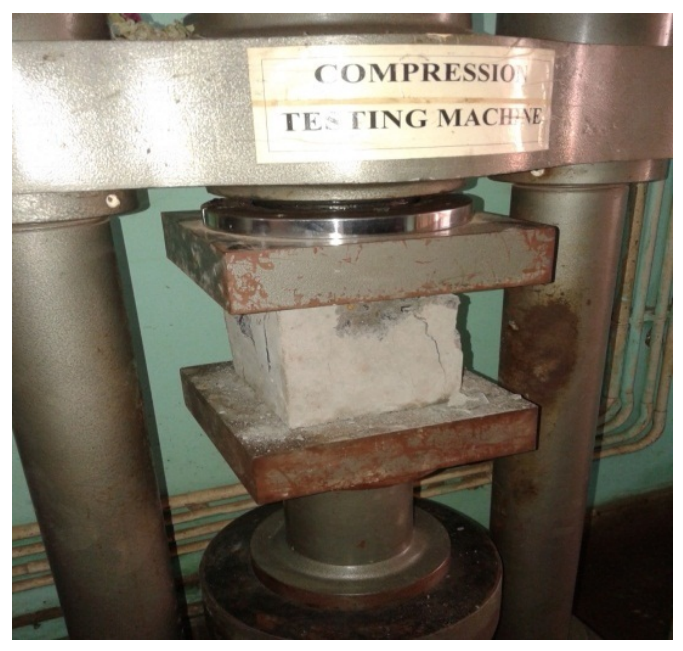

Fig. 3. Compressive strength test by CTM

and bequeaths high compressive strength.

Compressive strength developments at 56 and 90 days are compared with 28 days strength of the control concrete. Strength at 56 days has increased from the range 4.42 to $28.8 \%$ compared to the control concrete. At 90 days strength varied from 2.34 to $36.83 \%$ related to control concrete. But, strength is very nominally increased $(0.69 \%$ to $0.93 \%)$ at 56 and 90 days curing periods in control concrete. From this research, it is concluded that compressive strength of concrete with FA and CS is always higher than control concrete. Here, the positive effect of 
Tab. 5. Experimental Programme

\begin{tabular}{|c|c|c|c|}
\hline Type & Test Name & Test Standards & Specimen details \\
\hline \multirow{3}{*}{ Destructive testing } & Compressive strength & $\begin{array}{c}\text { IS516-1959/ (BSEN12390: } \\
\text { Part3:2009) }\end{array}$ & $\begin{array}{c}3 \text { Nos } 150 \times 150 \times 150 \mathrm{~mm} \text { cubes at } \\
7,28,56 \text { and } 90 \text { days per round } \\
\text { total: } 288 \text { specimens }\end{array}$ \\
\hline & Split Tensile strength & $\begin{array}{l}\text { IS 516-1959/ (BSEN12390:Part } \\
6: 2009)\end{array}$ & $\begin{array}{c}3 \text { Nos } 150 \text { mmdia } \times 300 \text { mmheight } \\
\text { cylinders per round total:72 } \\
\text { specimens }\end{array}$ \\
\hline & Flexural strength test & $\begin{array}{c}\text { IS 516-1959/ (BSEN12390: } \\
\text { Part5:2009) }\end{array}$ & $\begin{array}{c}3 \text { Nos } 100 \times 100 \times 500 \mathrm{~mm} \text { prisms } \\
\text { at } 28 \text { days per round total: } 72 \\
\text { specimens }\end{array}$ \\
\hline \multirow[t]{2}{*}{ Non-Destructive testing } & Ultra sonic pulse velocity & $\begin{array}{c}\text { IS 13311(Part1)1992/ (BS EN } \\
12504-4: 2004)\end{array}$ & \multirow{2}{*}{$\begin{array}{l}\text { Before conducting destructive test } \\
\text { Non-destructive } \\
\text { testing is conducted in the same } \\
\text { specimen at } 28 \text { days only }\end{array}$} \\
\hline & Rebound Hammer & $\begin{array}{c}\text { IS 13311(Part2)1992/ (BS EN } \\
\text { 12504-2:2001) }\end{array}$ & \\
\hline
\end{tabular}

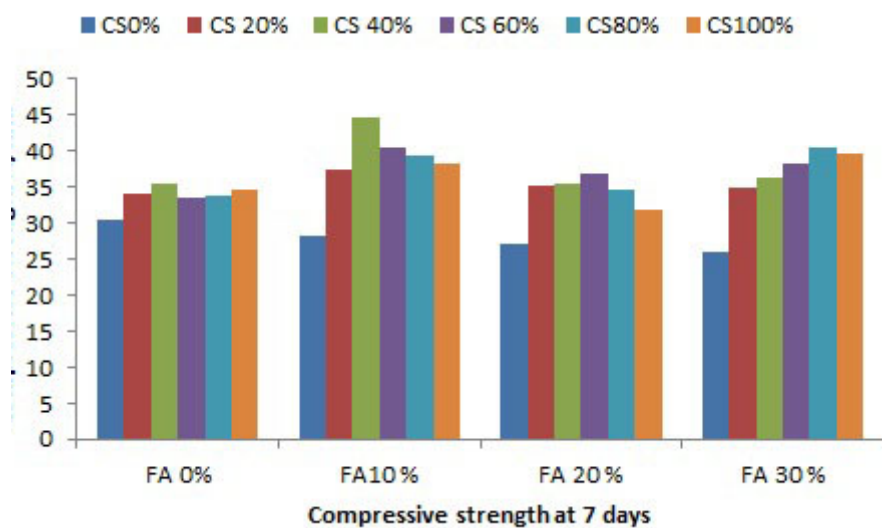

Fig. 4. Compressive strength at 7 days

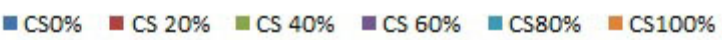

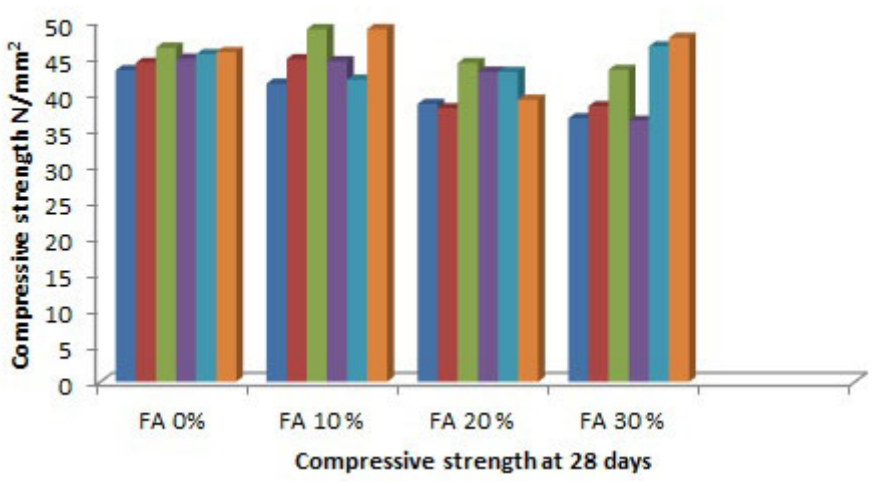

Fig. 5. Compressive strength at 28 days

copper slag compensates the strength loss due to the presence of FA. It is also suggested that, concrete with $30 \%$ FA replacement for cement and $80 \%$ CS replacement for fine aggregate is suitable for concrete structures.

The above observations are supported by the work of other researchers who studied the influence of CS as fine aggregate on the strength of mortars and concrete specimens [1]. The study has concluded that the mortars containing the larger amounts of CS have lower early strength at W/C ratio of 0.48 and that the strength of mixtures with $20-80 \%$ substitution of slag is higher than that of control specimens. Suresh Chandra Pattanaik and

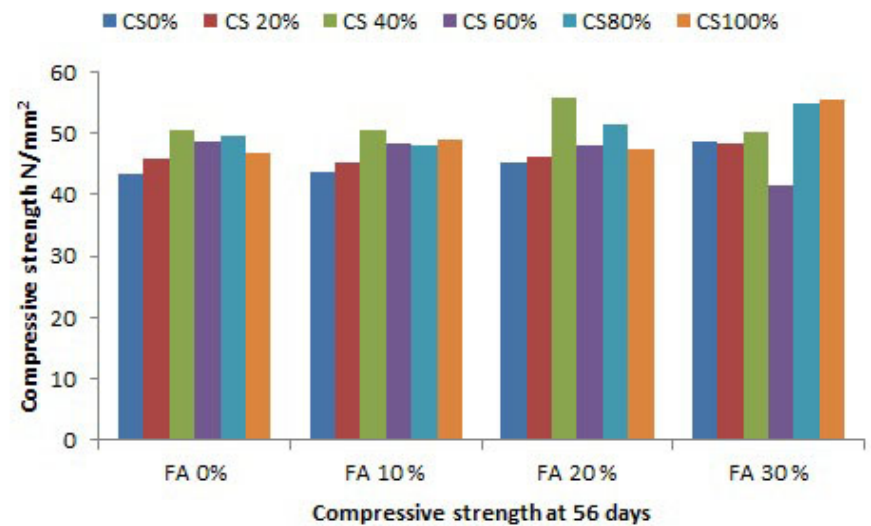

Fig. 6. Compressive strength at 56 days

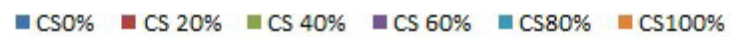

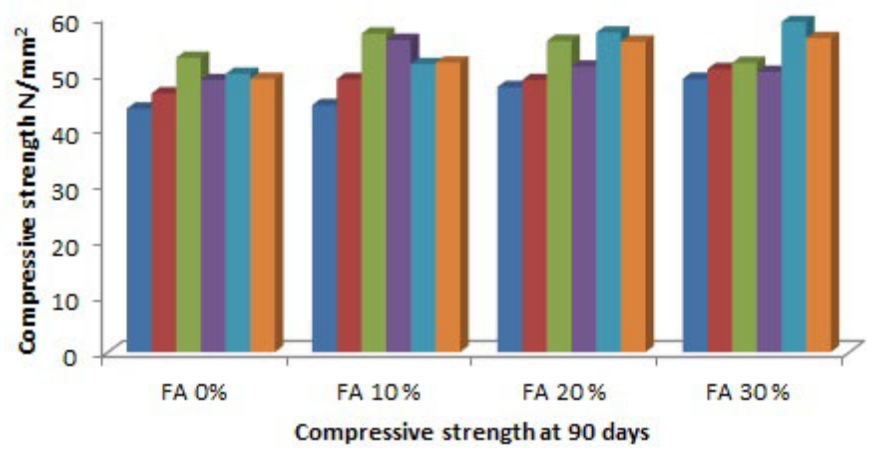

Fig. 7. Compressive strength at 90 days

Dr.Akshaya Kumar Sabat [11] have investigated the replacement of cement from $10 \%-40 \%$ by FA. The results have indicated that the strength of the mix with $40 \%$ replacement with fly ash is all the time lower than that of control mix. But, the rate of gain of strength of all mixtures replaced with FA from $10-30 \%$ is higher than control mixes.

\subsection{Split Tensile and Flexural tensile strength}

The results of the splitting tensile strength $(150 \mathrm{~mm}$ diameter $\times 300 \mathrm{~mm}$ height) and flexural strength $(100 \mathrm{~mm} \times 100 \mathrm{~mm} \times 500 \mathrm{~mm}$ prisms $)$ at 28 days are obtained in this study according to the procedures described in 
Tab. 6. Relation between Compressive and Tensile strength of Concrete

\begin{tabular}{|c|c|c|c|c|c|c|c|}
\hline \multicolumn{2}{|c|}{$\begin{array}{c}\text { Replacement \% of Fly ash } \\
\text { and Copper slag }\end{array}$} & \multirow{2}{*}{$\begin{array}{c}\text { Average } \\
\text { compressive } \\
\text { Strength } \\
\left(\mathrm{N} / \mathrm{mm}^{2}\right)\left(\sigma_{c}\right)^{28} \\
43.20\end{array}$} & \multirow{2}{*}{$\begin{array}{c}\begin{array}{c}\text { Average Split } \\
\text { tensile Strength } \\
\left(\mathrm{N} / \mathrm{mm}^{2}\right)\left(\sigma_{t}\right)^{28}\end{array} \\
3.3\end{array}$} & \multirow{2}{*}{$\begin{array}{c}\text { Average } \\
\text { Flexural } \\
\text { Strength } \\
\left(\mathrm{N} / \mathrm{mm}^{2}\right)\left(\sigma_{b}\right)^{28} \\
6.36\end{array}$} & \multirow{2}{*}{$\frac{\left(\sigma_{b}\right)^{28} /\left(\sigma_{c}\right)^{28}}{0.15}$} & \multirow{2}{*}{$\frac{\left(\sigma_{t}\right)^{28} /\left(\sigma_{c}\right)^{28}}{0.08}$} & \multirow{2}{*}{$\frac{\left(\sigma_{t}\right)^{28} /\left(\sigma_{b}\right)^{28}}{0.52}$} \\
\hline FAO & CSO & & & & & & \\
\hline FAO & CS20 & 44.23 & 3.6 & 6.42 & 0.15 & 0.08 & 0.56 \\
\hline FAO & CS40 & 46.34 & 3.91 & 6.76 & 0.15 & 0.08 & 0.58 \\
\hline FAO & CS60 & 44.81 & 3.72 & 6.52 & 0.15 & 0.08 & 0.57 \\
\hline FAO & CS80 & 45.42 & 3.68 & 6.46 & 0.14 & 0.08 & 0.57 \\
\hline FAO & CS100 & 45.71 & 3.61 & 6.41 & 0.14 & 0.08 & 0.56 \\
\hline FA10 & CSO & 41.34 & 3.28 & 6.31 & 0.15 & 0.08 & 0.52 \\
\hline FA10 & CS20 & 44.74 & 2.97 & 6.41 & 0.14 & 0.07 & 0.46 \\
\hline FA10 & CS40 & 48.9 & 4.03 & 6.88 & 0.14 & 0.08 & 0.59 \\
\hline FA10 & CS60 & 44.45 & 3.94 & 6.53 & 0.15 & 0.09 & 0.60 \\
\hline FA10 & CS80 & 41.9 & 3.91 & 6.48 & 0.15 & 0.09 & 0.60 \\
\hline FA10 & CS100 & 48.90 & 3.80 & 6.4 & 0.13 & 0.08 & 0.59 \\
\hline FA20 & CSO & 38.51 & 3.2 & 6.1 & 0.16 & 0.08 & 0.52 \\
\hline FA20 & CS20 & 37.93 & 3.5 & 6.78 & 0.18 & 0.09 & 0.52 \\
\hline FA20 & CS40 & 39.11 & 3.83 & 7.32 & 0.19 & 0.10 & 0.52 \\
\hline FA20 & CS60 & 42.96 & 3.75 & 6.59 & 0.15 & 0.09 & 0.57 \\
\hline FA20 & CS80 & 52.01 & 3.76 & 6.53 & 0.13 & 0.07 & 0.58 \\
\hline FA20 & CS100 & 45.48 & 3.4 & 6.5 & 0.14 & 0.07 & 0.52 \\
\hline FA30 & CSO & 36.53 & 3.12 & 5.8 & 0.16 & 0.09 & 0.54 \\
\hline FA30 & CS20 & 38.22 & 3.9 & 6.81 & 0.18 & 0.10 & 0.57 \\
\hline FA30 & CS40 & 43.26 & 4.1 & 7.21 & 0.17 & 0.09 & 0.57 \\
\hline FA30 & CS60 & 33.78 & 3.54 & 6.8 & 0.20 & 0.10 & 0.52 \\
\hline FA30 & CS80 & 46.5 & 4.03 & 6.71 & 0.14 & 0.09 & 0.60 \\
\hline FA30 & CS100 & 47.70 & 3.76 & 6.68 & 0.14 & 0.08 & 0.56 \\
\hline
\end{tabular}

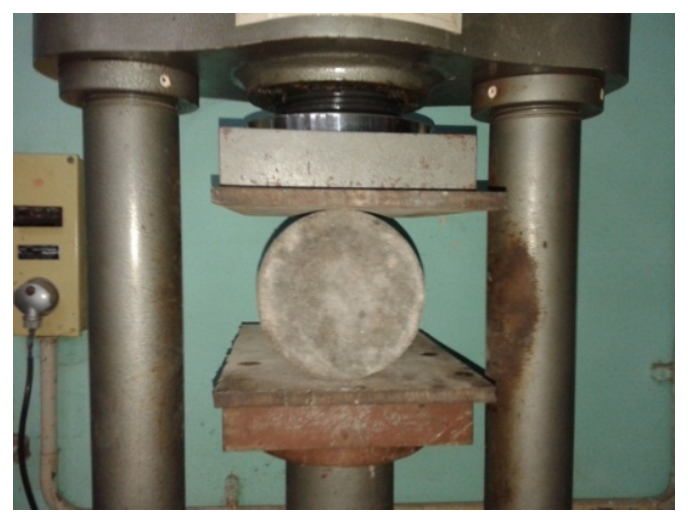

Fig. 8. Split tensile strength test

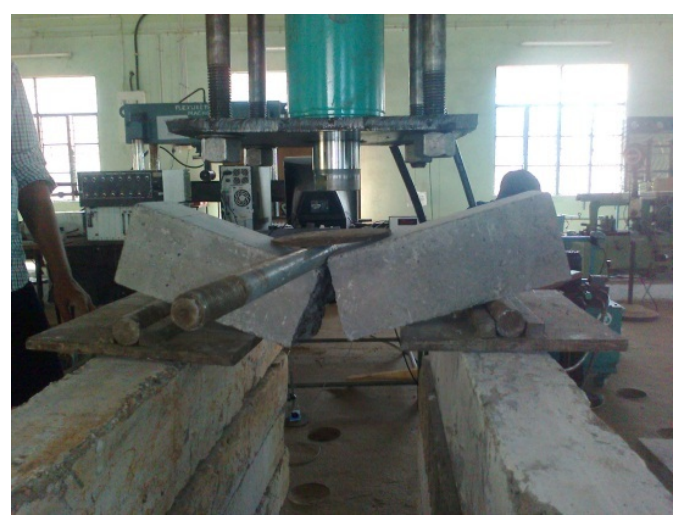

Fig. 9. Flexural strength

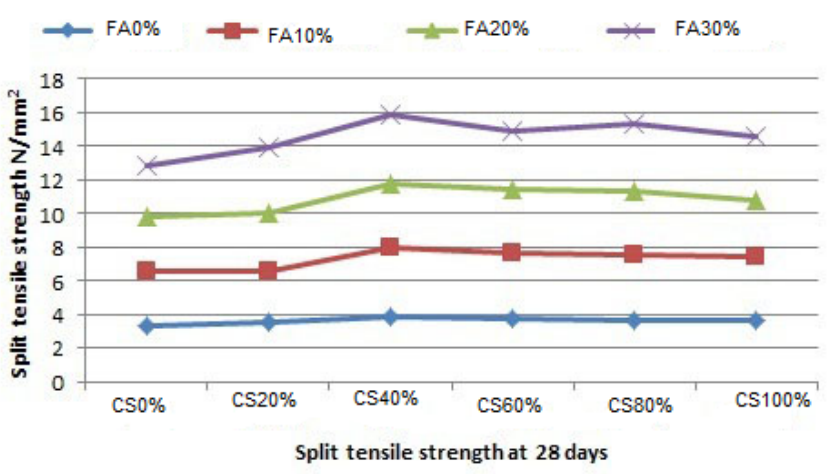

Fig. 10. Split tensile strength test at 28 days

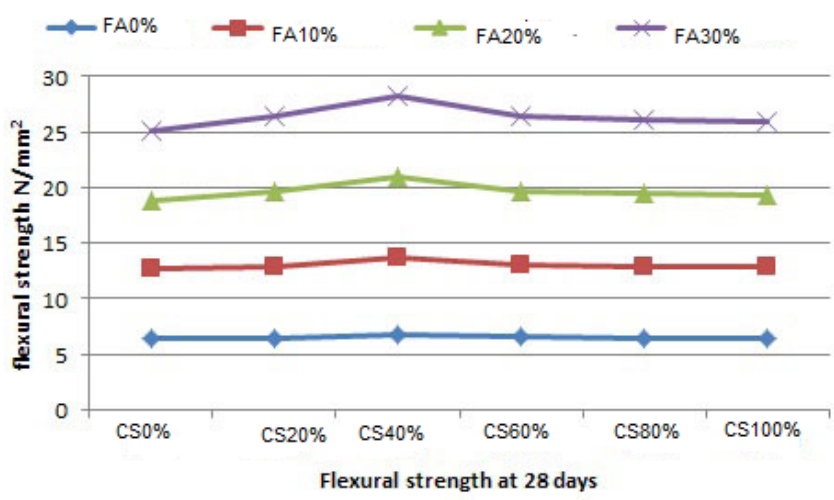

Fig. 11. Flexural tensile trength test at 28 days 
IS516-1959 [25] [Fig. 8] and Fig. 9]. Results are represented in the figures [10,11]. From the experimental results illustrate that the split tensile and the flexural strength behave in similar manner. The optimum strength reaches when concrete with FA $0 \%-30 \%$ replacement for cement and $40 \%$ CS replacement for fine aggregate. After that, strength profiles are declined. Tensile strength at 28 days varies from $1.52-24.24 \%$ which is $24.24 \%$ higher than that of the control concrete. Flexural strength for concrete at 28 days varies from $1.57-15.09 \%$. This is $15.09 \%$ higher than control mix. Up to $40 \% \mathrm{CS}$ in the mix increases the tensile strength of concrete. The reason for increased tensile strength may be a strong interface bond between the CS and FA paste. Irregular surfaces of CS aggregate particles are filled with hydration product. As a result they provide better bond strength and hence the tensile strength increases.

Usually, compressive strength is required in structural design and tensile strength is also required in structural design for certain specific applications, such as structures in earthquake regions, airfield runways, pavement slabs and so on [17].

\subsection{Relation between Compressive strength and Tensile strength}

In reinforced concrete construction, the strength of the concrete in compression is only taken into consideration. But, the design of concrete pavement slabs is often based on the flexural strength of concrete. Therefore, it is necessary to assess the flexural strength of concrete either from compressive strength or independently. The results of relation between compressive and tensile strength are given in Table 6 . From these results, it is seen that strength of concrete in compression and tension (both direct tension and flexural tension) are closely related. The ratio of the two strengths depends on general level of strength concrete. Based on the split tensile and the flexural strength experimental results, it is evident that concrete with up to $30 \%$ FA replacement for cement and $40 \%$ CS replacement for fine aggregate is suitable for pavement, runways and airfield construction.

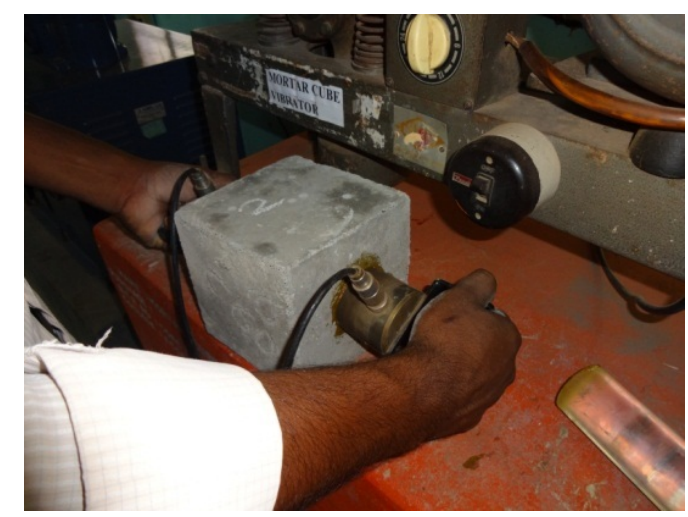

Fig. 12. Ultrasonic pulse velocity

\subsection{Non Destructive testing}

Before the compressive strength test is to be carried out by destructive testing techniques, the cubes were subjected to NDT methods such as UPV (Direct method - Fig. 12) and RH (Fig. 13) on the same specimens at 28 days only as per the procedure described in IS13311 (Part 1) 1992 and IS 13311(Part 2) 1992, respectively [27,28]. Results are given in Table 7

\subsubsection{Ultrasonic Pulse Velocity method}

The velocity of the propagation of ultrasound pulse is measured by direct transmission method using UX4600 ultrasound device. It is represented in the Fig. 12. From these results, UPV values for all the mix proportions vary from $4.0 \mathrm{~km} / \mathrm{s}$ to $4.7 \mathrm{~km} / \mathrm{s}$. In this experiment, velocity obtained is higher. This indicates that the quality of the concrete in terms of density, homogeneity and uniformity is good. Based on the IS code [27], velocities of concretes for all concrete mixture are indicated 'excellent and good'.

\subsubsection{Rebound Hammer test}

In RH method, compressive strength is directly measured by DIGI Schmidt (2000) Rebound Hammer (Proceq). It is portrayed in the Fig. $13 \mathrm{RH}$ strengths of all the mix proportions achieve the required strength for M30 grade of concrete at 28 days and also the results are comparable with control concrete. But, the strengths are largely scattered compared to compressive strength obtained by destructive testing results. The estimation of strength of concrete by rebound hammer method cannot be held to be very accurate and probable accuracy of prediction of concrete strength in a structure is \pm 25 percent [28]. This is because the RH results are affected by number of factors like surface condition and moisture content, age of concrete etc. RH values are also indicative of compressive strength of concrete to a limited depth from the surface. If the concrete has internal micro cracking, flaws or heterogeneity across the cross-section, RH strength will not indicate the same. But UPV values indicate that the concrete has uniform homogeneity, less amount of cracks, voids and other imperfections. From these results, it is concluded that both the NDT and the DT techniques results are favorable for concrete with industrial wastes such as FA and CS. Compressive strengths obtained by destructive testing results are compared with UPV and RH.

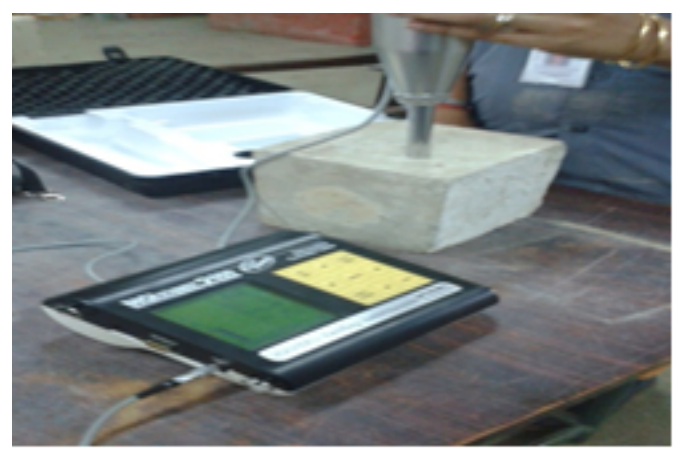

Fig. 13. Compressive strength test by $\mathrm{RH}$ 
Tab. 7. Non Destructive testing of Concrete by Ultrasonic Pulse Velocity and Rebound hammer

\begin{tabular}{|c|c|c|c|c|}
\hline \multicolumn{2}{|c|}{$\begin{array}{c}\text { Replacement \% of Fly ash } \\
\text { and Copper slag }\end{array}$} & \multicolumn{2}{|c|}{$\begin{array}{l}\text { Ultrasonic Pulse velocity } \\
\text { velocity } 28 \text { days curing concrete }\end{array}$} & \multirow{2}{*}{$\begin{array}{c}\text { Rebound hammer } 28 \\
\text { days curing concrete } \\
\text { Average compressive } \\
\text { strength } \mathrm{N} / \mathrm{mm}^{2} \text { as per } \\
\text { IS13311(Part II)1992 }\end{array}$} \\
\hline & & Pulse velocity km/s & $\begin{array}{l}\text { Quality of Concrete as } \\
\text { per IS 13311(Part I)1992 }\end{array}$ & \\
\hline FA0 & CSO & 4.5 & Good & 31.2 \\
\hline $\mathrm{FAO}$ & CS20 & 4.3 & Good & 32.1 \\
\hline FA0 & CS40 & 4.5 & Good & 34.51 \\
\hline FA0 & CS60 & 4.6 & Good & 35.26 \\
\hline FA0 & CS80 & 4.5 & Good & 34.5 \\
\hline FA0 & CS100 & 4.3 & Good & 33.4 \\
\hline FA10 & CSO & 4.2 & Good & 31.6 \\
\hline FA10 & CS20 & 4.65 & Excellent & 38.8 \\
\hline FA10 & CS60 & 4.44 & Good & 36.5 \\
\hline FA10 & CS80 & 4.3 & Good & 38.8 \\
\hline FA10 & CS100 & 4.5 & Good & 37 \\
\hline FA20 & CSO & 4.2 & Good & 32.4 \\
\hline FA20 & CS20 & 4.57 & Good & 37 \\
\hline FA20 & CS40 & 4.5 & Good & 32 \\
\hline FA20 & CS60 & 4.5 & Good & 31.8 \\
\hline FA20 & CS80 & 4.3 & Good & 33.5 \\
\hline FA20 & CS100 & 4.8 & Excellent & 37.6 \\
\hline FA30 & CSO & 4.3 & Good & 31.4 \\
\hline FA30 & CS20 & 4.31 & Good & 30.2 \\
\hline FA30 & CS40 & 4.73 & Excellent & 34.33 \\
\hline FA30 & CS100 & 4.5 & Good & 37 \\
\hline
\end{tabular}

Tab. 8. Regression equation for compressive strength (DT) and UPV

Replacement \% of Fly ash and Copper slag

\begin{tabular}{ll} 
FA0 & CS0\% to CS100\% \\
FA10 & CS0 $\%$ to CS $100 \%$ \\
FA20 & CS0 $\%$ to CS $100 \%$ \\
FA30 & CS0 $\%$ to CS100\% \\
\hline
\end{tabular}

Compressive strength (DT) -

dependent variable and $\quad \mathbf{R}^{2}$ value

UPV-independent variable

$y=-38.458(U P V)^{2}+343.76(U P V)-722.41 \quad 0.8855$

$\mathrm{y}=17.117(\text { UPV })^{2}-136.31(U P V)+311.86 \quad 0.8038$

$y=121.85(U P V)^{2}-1063.8(U P V)+2360.1 \quad 0.825$

$\mathrm{y}=-87.458(U P V)^{2}+800.38(U P V)-1785.1 \quad 0.8209$

Tab. 9. Regression equation for compressive strength (DT) and RH

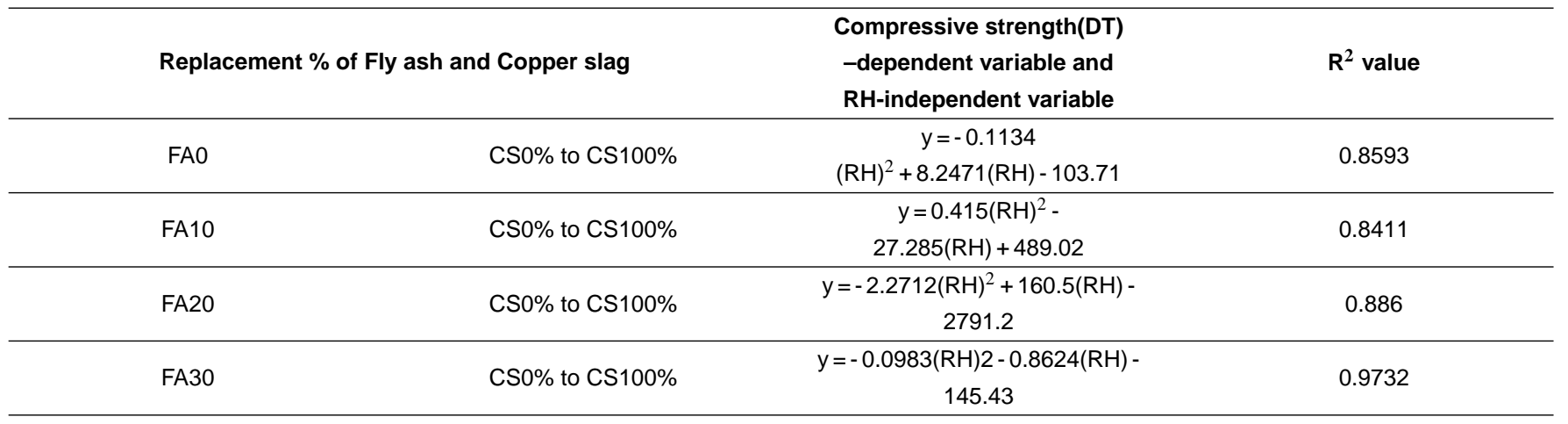




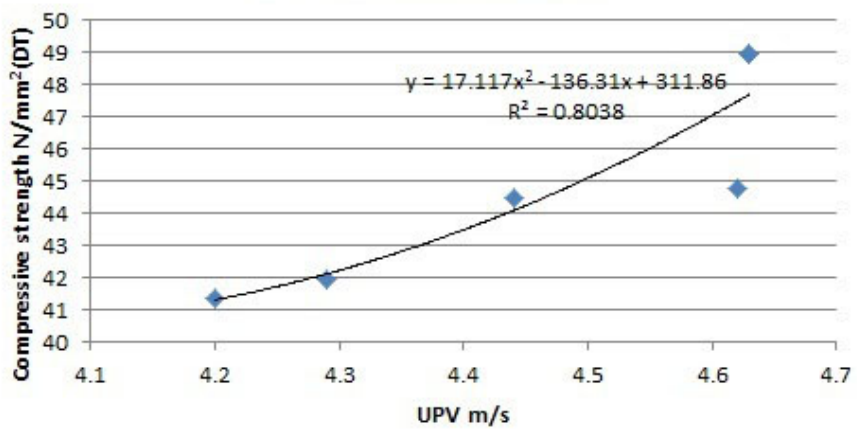

Fig. (a)

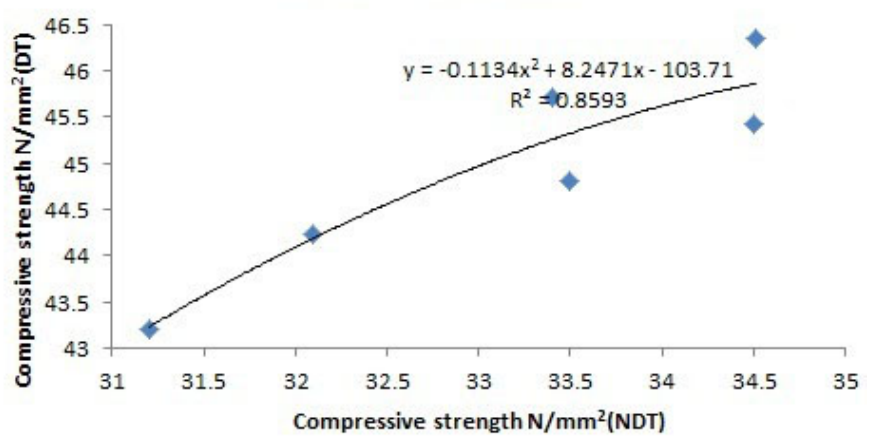

Fig. (c)

Fig. 14. (a - d) Correlation between DT and NDT

\subsection{Analysis of test results}

In order to estimate the effect of copper slag and fly ash on mechanical behaviour such as destructive (DT) and non destructive (UPV and $\mathrm{RH}$ ) a regression analysis (curve fitting techniques ) was used. In this study, regression equation were created between the results obtained from the destructive testing and non-destructive testing. MS-Excel is used to create the non linear regression equation. The experimental values are plot in graphs and also regression equation and co-efficients $\left(\mathrm{R}^{2}\right)$ are obtained from this model, and it is represented by Fig. 14[a-d]. The $\mathrm{R}^{2}$ value varied from to 0.8038 to 0.9732 . The $\mathrm{R}^{2}$ value an estimate of goodness of fit of the function to the experimental data. Its value represents the fraction of the overall variance of the dependent variable that is explained by the independent variable. Regression coefficient values are indicated that the difference between expected and estimated values slightly scattered and polynomial second order equations are given in Table 8 and Table 9

\section{Conclusions}

From the laboratory results, the following conclusions are made.

1 Concrete with FA alone, the initial rate of gain of compressive strength has been decreased due to slow pozzolanic action, but the strength is developed at later ages (56-90 days) higher than the control mix.

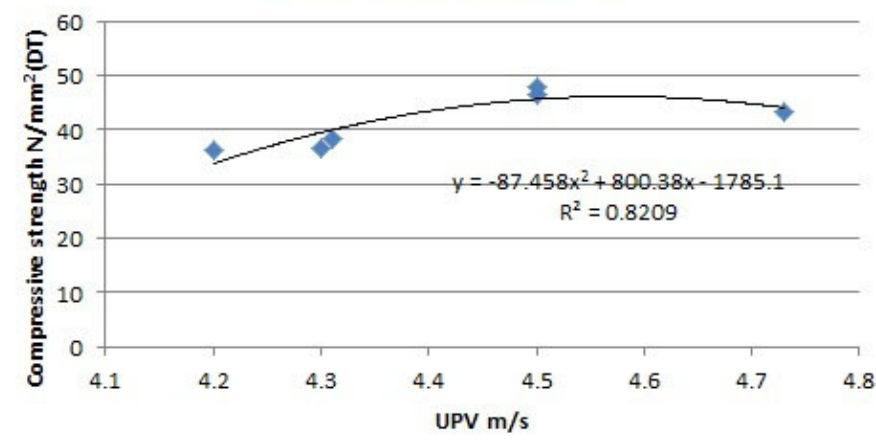

Fig. (b)

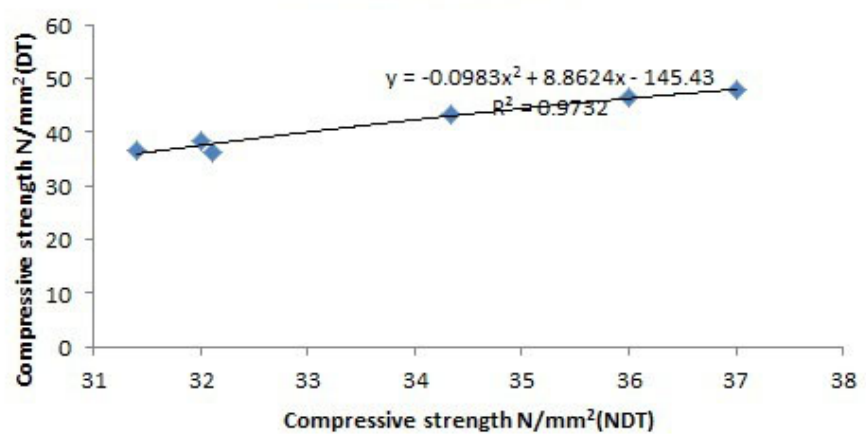

Fig. (d)

2 Compressive strength concrete incorporating with industrial waste such as FA and CS is increased from the early ages to lateral ages due the positive effects of CS compensate the strength loss due to the presence of FA. This indicates that, FA and CS react with surplus lime resulting from hydration of cement and give additional binding property continuously to the concrete. Hence, industrial wastes haven't affected the compressive strength.

3 Based on 90 days compressive strength, concrete mixtures with $30 \%$ of FA and $100 \%$ of CS have contributed higher strength than the control mix for all the time. Optimum strength is reached, when concrete with cement is replaced by $30 \%$ of FA and $80 \%$ of CS for fine aggregate. It is $36.83 \%$ better than the strength of control mix and also this mix proportion is suitable for concrete structures.

4 Based on the split tensile and flexural strength, concrete with up to $30 \%$ FA replacement for cement and $40 \%$ CS replacement for fine aggregate is suitable for pavement, runways and airfield construction.

5 UPV for all the mixtures varies from $4.0 \mathrm{~km} / \mathrm{s}$ to $4.7 \mathrm{~km} / \mathrm{s}$. These results reveal that, the concrete has uniform homogeneity, with fewer amounts of cracks, voids and other imperfections.

$6 \mathrm{RH}$ strengths of all mix proportions achieve required strength for M30 grade of concrete at 28 days. But, it is largely scat- 
tered compared to the strength obtained by destructive testing techniques. Since RH strength results are affected by some factors like properties of the aggregate, mix proportions, surface texture and surface wetness of the concrete. It is clear that the RH reflects only the concrete surface properties.

7 Polynomial second order (nonlinear) regression equations are well fitted to experimental results.

8 From both NDT and DT techniques, the results are favorable for concrete with industrial wastes such as Fly Ash and Copper Slag.

\section{Acknowledgement}

The authors wish to acknowledge Alagappa Chettiar College of Engineering and Technology, karaikudi, Sterlite Industries (India) Ltd.,Tuticorin, India and Thermal power plant Salem,India for providing all the facilities for carrying out this work.

\section{References}

1 Gorai B, Jana RK, Premchand, Characteristics and utilisation of copper slag-a review, Resources, Conservation and Recycling, 39(4), (2003), 299313, DOI 10.1016/S0921-3449(02)00171-4

2 Nath P, Sarker P, Effect of fly ash on the durability properties of high strength concrete, In: The twelfth Asia-Pacific Conference on Structural Engineering and Construction 2011, 2011, pp. 1149-1156.

3 Al-Jabri KS, Hisada M, Al-Oraimi SK, Al-Saidy AH, Copper slag as sand replacement for high performance concrete, Cement and Concrete Composites, 31(7), (2009), 483-488, DOI 10.1016/j.cemconcomp.2009.04.007

4 Wu W, Zhang W, Ma G, Optimum content of copper slag as a fine aggregate in high strength concrete, Materials and Design, 31(6), (2010), 2878-2883, DOI 10.1016/j.matdes.2009.12.037

5 Alnuaimi AS, Effects of copper slag as a replacement for Fine aggregate on the behavior and ultimate strength of reinforced concrete slender columns, The Journal of Engineering Research (TJER), 9(2), (2012), 90-102.

6 Pundhir NKS, Kamaraj C, Nanda PK, Use copper slag as construction material in bituminous pavements, Journal of Scientific and Industrial Research, 64, (2005), 997-1002.

7 Brindha D, Nagan S, Durability Studies on Copper slag Admixed Concrete, Asian Journal of Civil Engineering, 12(5), (2011), 563-578.

8 Alp I, Deveci H, Sungun $\mathbf{H}$, Utilization of flotation wastes of copper slag as raw material in cement production, Journal of Hazardous Materials, 159(23), (2008), 390-395, DOI 10.1016/j.jhazmat.2008.02.056

9 Mobasher B, Devagupta R, Arino AM, Effect of copper slag on the hydration of blended cementitious mixtures, In: Chong $\mathbf{K}$ (ed.), Proceeding, ASCE, Materials engineering conference , material for new millennium, 1996, pp. 1677-86.

10 Arino AM, Mobasher B, Effect of ground copper slag on strength and toughness of cementitious mixes, ACI Materials Journal, 96(1), (1999), 6873.

11 Pattanaik SC, Sabat AK, A study of NALCO Fly ash on compressive strength for effective use in high volume mass concrete for a sustainable development, In: International Conference on sustainable Technologies for concrete Constructions by India Chapter of American concrete Institute; Mumbai, 2010-09-03 and 2010.

12 Lokeshappa B, Dikshit AK, Disposal and Management of fly ash, In: 2011, International Conference on Life Science and Technology, pp. 11-14.
13 Atis CD, Heat evolution of high-volume fly ash concrete, Cement and Concrete Research, 32(5), (2002), 751-756, DOI 10.1016/S00088846(01)00755-4

14 Sanjayan JG, Hydration temperatures in large high-strength concrete columns incorporating slag, Cement and Concrete Research, 30(11), (2000), 1791-1799, DOI 10.1016/S0008-8846(00)00387-2

15 Pazhani K, Jeyaraj R, Study on durability of high performance concrete with industrial wastes, Applied Technologies and Innovations, 2(2), (2010), 19-28, DOI 10.15208/ati.2010.11

16 Peter A, Neelamegam M, Dattatreya JK, Rajamane NP, Gopalakrishnan S, Utilization of Fly ash as cement replacement material to produce high performance concrete, SERC,CSIR Campus, Taramani, Chennai, eprints.nmlindia.org/2443/1/38-49.pdf

17 Gencel O, Koksal F, Ozel C, Brostow W, Combined effects of fly ash and waste ferrochromium on properties of concrete, Construction and Building Materials, 29, (2012), 633-640, DOI 10.1016/j.conbuildmat.2011.11.026

18 Bagheri A, Zanganeh H, Alizadeh H, Shakerinia M, Marian MAS, Comparing the performance of fine fly ash and silica fume in enhancing the properties of concretes containing fly ash, Construction and Building Materials, 47, (2013), 1402-1408, DOI 10.1016/j.conbuildmat.2013.06.037

19 Jaina A, Kathuria A, Kumar A, Verma Y, Murari K, Combined Use of Non-Destructive Tests for Assessment of Strength of Concrete in Structure, Procedia Engineering, 54, (2013), 241-251, DOI 10.1016/j.proeng.2013.03.022 The 2nd International Conference on Rehabilitation and Maintenance in Civil Engineering (ICRMCE).

20 Agunwambaa JC, Adagbab T, A Comparative analysis of the Rebound hammer and Ultrasonic pulse velocity in testing concrete, Nigerian Journal of Technology (NIJOTECH), 31(1), (2012), 31-39.

21 Abbas AA, Kheder GF, Al-Owaisy RA, Use of combined Nondestructive test methods to predict concrete compressive strength concrete with aggregates obtained from Southern parts of Iraq, Al-Qadisiya Journal for Engineering Sciences, 3(3), (2010), 244-255.

22 Bureau of Indian Standards, 2013, http:law.resource.org/pub/in/ bis/so3/is.8112.2013.pdf

23 Bureau of Indian Standards, 2003, http:law.resource.org/pub/in/ bis/so3/is.812.1.2003.pdf

24 Bureau of Indian Standards, 1970, http:law.resource.org/pub/in/ bis/so3/is.383.1970.pdf

25 Bureau of Indian Standards, 2009, http:law.resource.org/pub/in/ bis/so3/is.10262.2009.pdf

26 Bureau of Indian Standards, 1959, http:law.resource.org/pub/in/ bis/so3/is.516.1959.pdf

27 Bureau of Indian Standards, 1992, http:law.resource.org/pub/in/ bis/so3/is.13311.1.1992.pdf

28 Bureau of Indian Standards, 1992, http:law.resource.org/pub/in/ bis/so3/is.13311.2.1992.pdf 